\title{
Effects induced after the use of maxillary protraction appliances: A literature review
}

Adanai de Brito Freire', Leonard Euler Andrade Gomes do Nascimento ${ }^{2}$, Ana de Lourdes Sá de Lira ${ }^{3}$

Objective: The present literature review, examined the effects of maxillary protraction in patients treated with different types of facial masks.

Methods: The review searched for relevant articles, including randomized controlled trials, controlled clinical trials and uncontrolled trials. Comparisons were made between eight different types of facial masks: Delaire; Grummons; Petit; Turley; Batista; "Sky Hook"; Nanda and Türbinger. Following aspects were evaluated: a) the type of anchorage; the origin, direction and magnitude of forces and $\mathrm{b}$ ) the relevant results of following skeletal and dental measurements: angular (SNA and SNB), linear (AFAI); vertical angles (SN.GoGn, FMA); dental (IMPA) and linear (1-NA, 1-NB).

Conclusion: The results showed that there was no uniformity in the choice of anchorage type and form of application of forces between the facial masks examined, but there were similarities in skeletal and dental aspects: Anterior displacement of the maxillary complex (increase in SNA) ; anterior displacement of the upper anterior teeth (increase of 1-NA), the lingual inclination of mandibular incisors (decrease of 1-NB), down and back rotation of the mandible (increase AFAI, SN.GoGn, FMA, decrease in SNB).

Keywords: Headgear Appliances. Angle Class III malocclusion. Maxilla.

${ }^{1}$ Specialist in Orthodontics, UFPI.

${ }^{2}$ MSc in Dentistry, UFRJ. Professor of the Orthodontics Specialization course, UFPI.

${ }^{3}$ MSc in Dentistry, UFRJ. PhD in Orthodontics. Professor of the Orthodontics Specialization course, UFPI.
How to cite this article: Freire AB, Nascimento LEAG, Lira ALS. Effects induced after the use of maxillary protraction appliances: A literature review. Dental Press J Orthod. 2012 July-Aug;17(4):122-8.

Submitted: March 03, 2010 - Revised and accepted: October 04, 2011

» The authors report no commercial, proprietary or financial interest in the products or companies described in this article.

Contact address: Leonard Euler Andrade Gomes do Nascimento R. Senador Cândido Ferraz, 1770 - Jockey - CEP: 64.049-250

Teresina/PI - Brazil - E-mail: leonardeuler@hotmail.com 


\section{Efeitos induzidos após uso de aparelhos para tração reversa da maxila: uma revisão de literatura}

Adanai de Brito Freire', Leonard Euler Andrade Gomes do Nascimento², Ana de Lourdes Sá de Lira ${ }^{3}$

Objetivo: o presente trabalho de revisão de literatura consistiu em realizar um estudo comparativo entre diversos modelos de máscaras faciais em relação às suas influências dentárias e esqueléticas e suas implicações sobre a altura facial inferior.

Métodos: optou-se pela busca de artigos relevantes, abrangendo estudos randomizados controlados, ensaios clínicos controlados e não-controlados, incluídos de acordo com critérios de elegibilidade. Foi realizada a comparação entre oito diferentes modelos de máscaras faciais: Delaire, Grummons, Petit, Turley, Batista, Sky Hook, Nanda e Tübinger. Foram coletados: a) o tipo de ancoragem, a origem, direção e magnitude das forças entre as máscaras faciais; e b) os resultados pertinentes às alterações das grandezas esqueléticas SNA e SNB, AFAI - ENA-Me, SN.GoGn, FMA; e as grandezas dentárias IMPA, 1-NA e 1-NB.

Conclusão: não houve uniformidade na escolha do tipo de ancoragem e forma da aplicação das forças entre as máscaras envolvidas no estudo. Houve semelhança nas grandezas esqueléticas e dentárias: deslocamento anterior do complexo maxilar (aumento do SNA), deslocamento anterior dos dentes superiores (aumento do 1-NA), inclinação lingual dos incisivos inferiores (diminuição do 1-NB e IMPA), rotação da mandíbula para baixo e para trás (aumento do AFAI, SN.GoGn e FMA, diminuição do SNB).

Palavras-chave: Má oclusão de Angle Classe III. Maxila. Aparelhos de tração extrabucal.

\footnotetext{
${ }^{1}$ Especialista em Ortodontia, UFPI.

${ }^{2}$ Mestre em Odontologia, UFRJ. Professor de Especialização em Ortodontia, UFPI. Doutorando em Ortodontia, UFRJ.

${ }^{3}$ Mestre em Odontologia, UFRJ. Professora de Especialização em Ortodontia, UFPI. Doutora em Ortodontia, UFRJ.
}

Como citar este artigo: Freire AB, Nascimento LEAG, Lira ALS. Effects induced after the use of maxillary protraction appliances: A literature review. Dental Press J Orthod. 2012 July-Aug;17(4):122-8.

Enviado em: 03 de março de 2010 - Revisado e aceito: 04 de outubro de 2011

» Os autores declaram não ter interesses associativos, comerciais, de propriedade ou financeiros, que representem conflito de interesse nos produtos e companhias descritos nesse artigo.

Endereço para correspondência: Leonard Euler Andrade Gomes do Nascimento R. Senador Cândido Ferraz, 1770 - Jockey - CEP: 64.049-250

Teresina/PI - E-mail: leonardeuler@hotmail.com 


\section{INTRODUCTION}

The first treatments relative to Class III malocclusions using facial mask were performed by Potpeschnigg $^{47}$ in 1875. In 1971, ${ }^{9}$ Delaire established the clinical use and popularization..$^{15,29,31,36}$ Over the years, authors ${ }^{1,11,28,37,43,44,48}$ modified Delaire's concepts related to: 1) the traction mechanics, increasing the quantity of force applied and reducing the treatment time; 2) the expander, using the acrylic occlusal covering as anchorage; and 3) the patient cooperation, with the use of personalized facial masks.

Within the treatment options for Class III malocclusions the following approaches can be usually found: Inclined plane, chin cap, facial mask, fixed appliances $^{30}$ and the Frankel functional regulator III. ${ }^{12}$ Hyrax, Haas or McNamara palatal disjunction are appliances used for median palatine suture disjunction (RME), which after accomplished, frees the craniofacial sutures and facilitates the desired anterior movement of the maxilla. Moreover, maxillary splinted teeth are maintained during the post-disjunction period (six to eight months) and used as anchorage for protraction by means of hooks for elastics..$^{27,38,49}$

The indications for protraction are: 1) young patients; 2) well-positioned or lingually inclined upper teeth; 3) normal or decreased inferior facial height; ${ }^{37,44}$ 4) Class III malocclusion with anteroposterior (AP) and/or vertical maxillary deficiency; ${ }^{44}$ and 5) slight to moderate skeletal Class III malocclusion, with retruded maxilla and hypodivergent growth pattern. ${ }^{37}$ The use of reverse pull facial masks are not indicated in patients with increased inferior facial height. A skeletal effect of the mask is an anterior movement of the upper teeth and downward-backward rotation, which contributes to a greater increase of the patient's inferior facial height at the end of the treatment. ${ }^{17,34,44}$ The existing devices contain variations in their classification with relation to extra-oral anchorage: a) occipital-mentum support (Sky Hook), b) fronto-mentum support (Delaire, Petit, Turley, Tübinger), c) frontoinfraorbital support (Grummons). ${ }^{23,26}$

Treatment with facial masks for early correction of Class III maxillary deficiency is completely dependent on a good level of cooperation by the patient. ${ }^{30,31}$ The growing interest in early treatment of this malocclusion has kindled the necessity of knowing the treatment approaches, types of masks, their mechanisms of action, indications, as well as knowledge of palatine disjunction and its mechanisms. The objective of this research was to perform a comparative study between the various types of facial masks and their dental and skeletal influences and the implications regarding the effect on inferior facial height.

\section{MATERIAL AND METHODS Literature review}

The strategy for this review was based on four data sources and internet gateways (Cochrane Central Register of Controlled Trials, Ovide ALL EMB Reviews, PubMed and Bireme) from January 1965 to May 2011, using the key-words: Class III malocclusion, reversepull, facial mask and rapid maxillary expansion. Two of the authors separately searched for additional relevant publications that may have been absent in the data banks (for example: Manual search of scientific articles in libraries and direct contact with the authors). There were no language restrictions. At first, the articles were selected by reading the titles and abstracts. The full text was obtained of publications that fulfilled the inclusion criteria (Tab 1). The selection of each article was evaluated independently, and at the second consensus, a $100 \%$ final agreement was obtained between the two authors.

\section{Collection of data}

After selection based on the inclusion criteria, the articles were used to compare the effects of eight different models of facial masks: Delaire, Grummons, Petit, Turley, Batista, Sky Hook, Nanda and Tübinger. The following data was selected from each article: a) the type of anchorage; the origin, direction and magnitude of force b) the results pertinent to the alterations in sagittal angles (SNA and SNB) and vertical (AFAI) skeletal measurements; vertical angles (SN.GoGn, FMA); angular (IMPA) and linear (1-NA, 1-NB) dental measurements.

\section{RESULTS}

\section{Strategies for literature review}

The search strategy resulted in 14 articles $^{2,3,6,7,8,16,21,25,33,34,40,41,42,50}$ selected according to the inclusion criteria, which were submitted to a comparison among eight different face mask models: Delaire; Grummons; Petit; Turley; Batista; "Sky Hook"; Nanda and Tübinger. 


\section{Data collection}

After evaluating the items: a) type of anchorage; origin, direction and magnitude of force applied (Tab 2), it was verified that besides chin and forehead support, other extra-oral anchorage sites exist for reverse-pull therapy such as midfacial, cervico-occipital-molar and cervico-mentum regions. Canines and molars are used as the origin of the forces, which varied in intensity, inclination and duration in hours per day, as well as not being standardized in treatment duration among the analyzed models.

In the analysis of the results pertinent to the alteration of the sagittal skeletal angular measures
(SNA and SNB); dental angular (IMPA) and linear (1-NA, 1-NB) measures, it was observed that with all models there was anteroinferior movement of the maxilla confirmed by the increase of SNA; clockwise rotation of the mandible with decrease in SNB; vestibularization of the upper incisors or compensation of the Class III with increase in 1-NA. With the lower teeth, there was a decrease in 1-NB, lingual inclination or compensation of the Class III (Tab 3).

In the analysis of the results pertinent to the alterations of vertical skeletal (AFAI) and vertical angular (SN.GoGn, FMA) measurements, and increase in AFAI, the SN.GoGn angle with mandibular clockwise

Table 1 - Inclusion criteria for the selection of articles.

\section{Type of search and study}

Type of sample

Indications for treatment

Type of palatine expander

Disjunctor activation protocol

Beggining of loading

Variation of force applied

Daily time of facial mask usage

Total treatment time

\section{Scientific articles, randomized clinical trial, controlled and non-controlled}

Involving humans aged $5-14$ years $(+/-0.63$ years $)$

Skeletal Class III and anterior crossbite

Hass, Hyrax

Cases without disjunction with use of an expanded removable plate with hooks or transpalatal bar

Minimum of 2/4 turns per day or every two days for three weeks

Start without disjunction or concurrently with disjunction or upon appearance of interincisal diastema or immediately after palatine disjunction

Ranging from 230 to $600 \mathrm{~g} / \mathrm{side}$

From 6 to 24 hours/day

From 2.5 to 12 months or until a positive overjet or Class I dental relationship was obtained

Legend: plo = occlusal plane; min = minute; gf = gram force; $\mathrm{N}=$ Newton .

Table 2 - Data collected from selected articles showing the differences in type of anchorage, origin, direction and magnitude of the forces.

\begin{tabular}{|c|c|c|c|c|c|c|}
\hline \multirow[t]{2}{*}{$\begin{array}{l}\text { Mask } \\
\text { Model }\end{array}$} & \multirow[t]{2}{*}{ Type of anchorage } & \multicolumn{2}{|r|}{ Force Direction } & \multicolumn{3}{|c|}{ Force Magnitude } \\
\hline & & Origin & Inclination degrees/opl & Intensity/side & Duration hours/day & Duration months \\
\hline Delaire $2,7,8,42$ & Fronto-mentum & Canines & $25^{7} ; 30-40^{8} ; 45^{42}$ & $\begin{array}{l}350 \mathrm{gf}^{7} ; 230-285 \mathrm{gf}^{8} \\
340 \mathrm{gf}^{42} ; 400-600 \mathrm{gf}^{2}\end{array}$ & $10-16^{7,8}$ & $6-12^{7,8,42}$ \\
\hline Grummons $^{21}$ & Fronto-mid-face & Molars & Anteroinferior & $0,5 \mathrm{~N}$ & 24 & 8 \\
\hline Petit $241,40,50$ & Fronto-mentum & Canines & $30^{40} ; 30-40^{50}$ & $\begin{array}{c}400-600 g^{2} ; \\
300-500 g f^{50} ; 600 g f^{41}\end{array}$ & $14-16^{2,40,50}$ & $3^{50} ; 8 \pm 2,5^{40}$ \\
\hline Turley $^{25,41}$ & Fronto-mentum & Canines & $20-30^{25}$ & $400 \mathrm{gf}^{25}$ orthopedic ${ }^{41}$ & $14-20^{25,41}$ & $6^{25}$ \\
\hline Baptista ${ }^{3,16}$ & Cervico-occipital-molar & Molars & Anteroinferior ${ }^{3,16}$ & $415 \mathrm{gf}^{3} ; 500 \mathrm{gf}^{16}$ & $14^{16}$ & $12^{3} ; 31^{16}$ \\
\hline Sky Hook ${ }^{6}$ & Cervico-mentum & Canines & Anteroinferior & $300 \mathrm{cN}$ & $12+1 \mathrm{~min}$ & 6 \\
\hline Nanda ${ }^{34}$ & Fronto-mentum & Molars & $\begin{array}{l}15 \mathrm{~mm} \text { above and parallel to } \\
\text { the opl }\end{array}$ & $300-450 \mathrm{gf}$ & $12-16$ & 6 \\
\hline Tübinger ${ }^{33,40}$ & Fronto-mentum & Canines & $30^{33,40}$ & $600 \mathrm{gf}^{40} ; 380 \mathrm{gf}^{33}$ & $12-14^{33} ; 16^{40}$ & $6^{33} ; 8 \pm 2,5^{40}$ \\
\hline
\end{tabular}


turn and increase of the FMA angle was noticed as a results of the facial mask types analyzed (Tab 4).

\section{DISCUSSION}

Correction of skeletal Class III malocclusion using maxillary protraction therapy results in a combination of bone and dental changes that entail significant improvements in facial profile. ${ }^{41}$ In the last few years, this type of therapy became common due to the significant influence of maxillary deficiency within this malocclusion providing useful results for young patients. ${ }^{50}$

It was observed that the majority of facial mask models used fronto-mentum support as extra-oral anchorage with vertical effect mainly for Class III patients with normal or decreased AFAI. The Baptista model, using the lower molar as anchorage and modified headgear, has a pleasant aesthetic effect, but with the high cost of adverse effects on these teeth and considerable limitations in the patient's opening of the mouth and speaking. The Sky Hook and Grummons models have more favorable aesthetic and vertical effects, being the best alternative for patients with increased AFAI. ${ }^{6,21}$ The absence of chin support on the Grummons model eliminated the force vector directed backward and upward, acting on the temporomandibular joint, compressing the ligaments and impairing mandibular movements involved in speaking, breathing and deglutition. ${ }^{21}$ Aside from frontomentum anchorage, the Nanda model uses a vertical chin cup concurrently to reduce effects on AFAI. ${ }^{34}$

For The majority of the models ${ }^{2,6,7,8,25,33,40,41,42,50}$ (Tab 2) the canine region was used as the origin of the force to avoid anterior bite opening and to enhance anteroinferior rotation of the maxilla and its influence on the mandibular clockwise rotation,improving the profile. ${ }^{24,45}$ This maxillary rotation can be affected by many factors including

Table 3 - Data collected from selected articles showing alterations in sagittal skeletal angular measures (SNA e SNB); dental angular (IMPA) and linear (1-NA, 1-NB) measures.

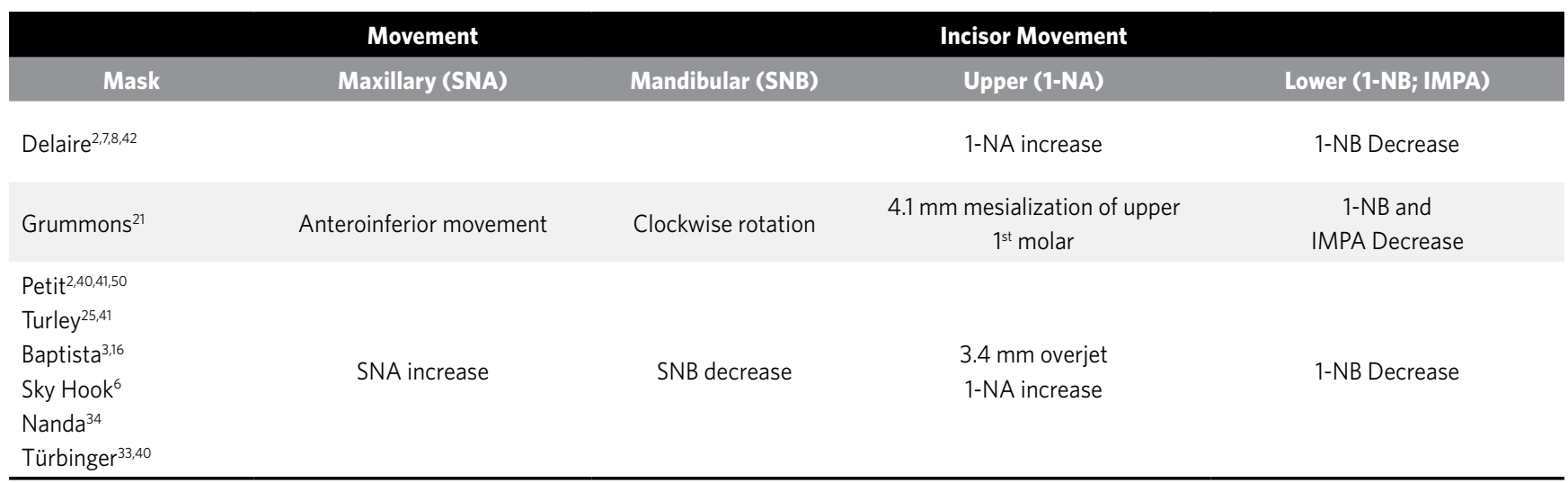

Table 4 - Data collected from the selected articles showing the linear sagittal (AFAI) skeletal measurements and vertical angles (SN.GoGn, FMA).

\begin{tabular}{|c|c|c|}
\hline \multirow{2}{*}{ Skeletal measurements } & Linear sagittal & Vertical angles \\
\hline & AFAl & SN.GoGn \\
\hline Delaire $2,7,8,42$ & Considerable increase & Increase \\
\hline $\begin{array}{c}\text { Grummons }{ }^{21} \\
\text { Petit } 2,40,41,50 \\
\text { Turley }^{25,41} \\
\text { Baptista }^{3,16}\end{array}$ & Increase - Profile improvement & Increase - Profile improvement \\
\hline Sky Hook & Increase & Increase: Discrete effect \\
\hline $\mathrm{Nanda}^{34}$ & Increase: Discrete effect & Increase: Discrete effect \\
\hline Türbinger ${ }^{33,40}$ & Increase & Increase \\
\hline
\end{tabular}


the point where the force is activated, the direction of elastic traction and the patient's facial pattern. ${ }^{50}$ Nanda used the molars due to the necessity of adapting the modified AEB to the tubes of these teeth, yet with force vectors passing through the center of the maxillary resistance to ensure movement of the maxilla with minimal rotation. ${ }^{34}$ The point of application of the force on the maxilla varies according to the necessity of each case. ${ }^{16}$ For upper arch traction, elastics originating from the upper first molars are used, while for other cases, ${ }^{21}$ elastics are placed transversely from the bands on deciduous molars to the facial mask, protecting the corners of the mouth.

No uniformity in relation to the value of the angulation to the occlusal plane and force vector could be found, varying from $20^{\circ}$ to $45^{02,7,8,25,33,34,40-42,50}$ (Tab 2). In some papers, only the following informations were given: "anteroinferior inclination"3,6,16,21 or "force vector $15 \mathrm{~mm}$ above and parallel to the occlusal plane with the line of action through the center of maxillary resistance favoring anterior movement with minimal clockwise maxillary inclination". ${ }^{34}$ In the encountered results, the force applied to each side of the maxilla varied between 230 gf to 285 gf/side, meanwhile authors ${ }^{8,41}$ suggest using orthopedic forces to pull the maxilla with forces of $230 \mathrm{~g}$ to $285 \mathrm{~g} .{ }^{8}$ The suture anatomy and age of the patient have an important role in determining the magnitude of the force necessary for maxillary protraction, because, maxillary sutures such as the zygomatic-maxillary, pterigo-palatine and nasomaxillary sutures become mechanically interlaced and sinuous in their trajectories, with numerous areas of bone remodeling (apposition, absorption, synostosis), which slightly resembles the median palatine suture in younger individuals. ${ }^{34}$

When evaluating the effects between the same models among different authors ${ }^{2,3,8,16,25,27,33,40,41,50}$ (Tab 2 ), there was no uniformity in relation to the amount of time of use per day, varying between 10 hours/day and 24 hours/day. Night time use is recommended due to the discomfort and appearance of the apparatus. In addition, and collaboration obtained in clinical practice is good if the minimal protocol of 8 to 10 hours is accepted (night time use). ${ }^{6}$ In the same manner, when comparing different models, ${ }^{2,3,6,7,8,16,21,25,33,34,40,41,42,50}$ there was no consistency in relation to the duration of the treatment varying from 6 to 31 months. The force is applied until positive overjet or Class I occlusion is obtained..$^{50}$ The device is monitored every 3 to 5 weeks, with force that is being increased being between 0.3 and $0.4 \mathrm{~N}$ on each side. ${ }^{21}$

In the Grummons model, without chin support, there was clockwise maxillary rotation, with increase in SNA, ANB and slight clockwise rotation of the maxillomandibular complex. ${ }^{21}$ With the Nanda model, there was a 1 to $3 \mathrm{~mm}$ translation of the maxilla and remodeling of the B point, improving the profile. ${ }^{34}$ There was distinct improvement in the sagittal maxillomandibular relation with alteration in the facial convexity, and medium increase of the ANB angle of $2.1^{0}{ }^{34}$ The use of expanders and quad-helix can be employed with extra-oral forces using the Batista device. ${ }^{3}$ Even without external chin support, there was clockwise mandibular rotation due to lower molar anchorage, and the vector of maxillary traction promoted maxillary protraction with clockwise rotation in the anteroinferior direction. ${ }^{3}$ Even varying the nomenclature among the authors, there was vestibular movement of the upper incisors, compensation of the Class III malocclusion with consequent increase of 1-NA in all models. ${ }^{51}$ With the Grummons model there was vestibularization of the upper incisors with a $3.4 \mathrm{~mm}$ average increase of the overjet. This effect could be caused by the compression of the soft tissue in the chin region as a consequence of chin support (Tab 3). ${ }^{50}$ In this model a posteroinferior biteplate was used with the plane inclined vestibularly stimulating anterior displacement of the maxilla and Hawley bow stimulating lingual inclination of the lower incisors.

In all models there was an increase in the AFAI, SN.GoGn and FMA angles, with consequent clockwise mandibular rotation. For the Grummons model, these results imply a better sagittal relation between the maxilla and mandible with a profile improvement. The AFAI increased due to facial growth. ${ }^{25}$ The anterior positioning of the hooks and use of the Sky Hook device denote concern with vertical displacement, triggering milder vertical components. ${ }^{6}$ Backward rotation of the mandible is similar to the results obtained in numerous previous studies investigating an assortment of modified facial masks, the main reason being the reduction of the SNB values and increase in SNGoGn. ${ }^{14}$ 
The mandibular rotation could be due to the vertical maxillary movement and retraction force on the chin, ${ }^{50}$ and eruption of the upper molars. ${ }^{7}$ This rotation influences anterior overjet, the skeletal maxillomandibular relationship, the facial convexity and increase of the AFAI. ${ }^{50}$ In the selected articles, it was observed that there was no relation in the aesthetic requirement in the perception by the patients, laypersons and professionals, since the facial mask could influence or interfere in the results of the treatments. The Sky Hook and Grummons models have less aesthetic compromise and vertical effects, being recommended for patients with increased AFAI. The Nanda model ${ }^{34}$ occasioned minimal mandibular rotation, showing that predictable changes can be achieved regarding the maxillary advancement, with desired mandibular changes or absence of undesired alterations, since altering the point of application of the force on the mask or on the external curve of the facial arch, the vertical dimension could be controlled satisfactorily. This fact is especially important for Class III patients with long vertical dimension and excessive mandibular plane angle. ${ }^{6}$

\section{CONCLUSIONS}

Upon analyzing the literature related to the effects of reverse-pull of the maxilla in patients treated with eight different models of facial masks, it was considered that:

a) There was no uniformity in choice of the extra and intraoral anchorage types, direction and magnitude of elastic forces and time necessary for the treatment duration.

b) There were similarities in skeletal and dental measurements: anterior displacement of the maxillary complex (increase in SNA); anterior displacement of upper teeth (increase in 1-NA); lingual inclination of lower incisors (decrease in 1-NB); backward-downward rotation of the mandible (increase in AFAI, SN.GoGn and FMS; decrease in SNB), resulting in significant improvement in facial profile and establishment of positive overjet.

\section{REFERENCES}

1. Almeida RR, Garib DG, Henriques JFC, Almeida MR. Ortodontia preventiva e interceptora: mito ou realidade? Rev Dental Press Ortodon Ortop Facial. 1999;4(6):87-108

2. Arman A, Toygar TU, Abuhijleh E. Profile changes associated with different orthopedic treatment approaches in Class III malocclusions. Angle Orthod. 2004;74(6):409-14

3. Baptista JM. Aparelho de tração reversa na maxila (BHG). In: Ortodontia Personalizada. São Paulo (SP): Ed. Santos; 2004.

4. Battagel JM. The etiological factors in Class III malocclusion. Eur J Orthod. 1993;15(5):347-70

5. Capelozza LF, Taniguchi SM, Silva filho OG. Expansão rápida e tração extrabucal reversa da maxila na dentadura mista: Comentários através de caso clínico. Ortodontia. 1990;23(3):66-78

6. Capelozza LF, Suguino R, Cardoso MA, Bertoz FA, Mendonça MR, Cuoghi OA. Tratamento ortodôntico da Classe III: revisando o método (ERM e Tração) por meio de um caso clínico. R Dental Press Ortodon Ortop Facial. 2002;(6):99-119.

7. Carlini MG, Miguel JAM, Goldner MTA. Tratamento precoce da má-oclusão Classe III de Angle com expansão rápida e uso de máscara facial: relato de um caso clínico. R Dental Press Ortodon Ortop Facial. 2002;7(2):71-5.
8. Chong Yea-Hwe, Ive JC, Artun J. Alterações após o uso da ancoragem extrabucal para protração a fim de realizar a correção precoce da má-oclusão Classe III. R Dental Press de Ortodon Ortop. 1997;2(4):52-53.

9. Delaire J. Confection du masque orthopédique. Rev Stomatol. 1971;72(5):579-82.

10. Dewey M. Practical Orthodontia. St. Louis (MO): Mosby; 1919.

11. Dietrich UC. Morphological variability of skeletal Class 3 relationships as revealed by cephalometric analysis. Rep Congr Eur Orthod Soc. 1970;131-43.

12. Frankel R. Maxillary retrusion in Class 3 and treatment with the function corrector 3. Rep Congr Eur Orthod Soc. 1970;249-59.

13. Goddard CL. Orthodontia. Philadelphia (PA): Lea Brothers; 1900.

14. Schatz MD, Göz G . Early treatment to correct Class III relations with or without facemasks. Angle Orthod. 2008;8(1):44-49.

15. Goh GK; Kaan SK. Dentofacial orthopedic correction of maxillary retrusion with the protaction facemask- a literature review. Aust Orthod J Brisbane. 1992;12(3):143-50.

16. Gonçalves Filho S, Chaves A, Benvenga MN. Apresentação de um caso clínico de Classe III de Angle, tratado com o aparelho extrabucal basculante inferior de ação reversa proposto por Baptista. R Dental Press Ortodon Ortop Facial. 2005;10(1):46-58.

17. McNamara J Jr. Tratamento de crianças na fase de dentição mista. In: Graber TM Ortodontia princípios e técnicas atuais. Rio de Janeiro (RJ): Guanabara Koogan; 2002. p. 467-96. 
18. Grandori F, Merlini C, Amelotti C, Piasente M, Tadini G, Ravazzani PA. Mathematical model for the computation of the forces exerted by the facial orthopedic mask. Am J Orthod Dentofac Orthop. 1992;101(5):441-8.

19. Haas A. Rapid expansion of the maxillary dental arch and nasal cavity by opening the midpalatal suture. Angle Orthod. 1961;31(2):73-90.

20. Hata S, Itoh T, Nakagawa M, Kamogashira K, Ichikawa K, Matsumoto M, et al. Biomechanical effects of maxillary protraction on the craniofacial complex. Am J Orthod Dentofacial Orthop. 1987;91(4): 305-11.

21. Hegmann $M$, Rüther AK. The Grummons face mask as an early treatment modality within a Class III therapy concept. J Orofac Orthop. 2003;64(6): 450-6.

22. Hellman M. A study of some etiological factors of malocclusion. Dent Cosmos. 1914:73(9):1017-32.

23. Hickham JH. Maxillary protraction therapy: diagnosis and treatment. J Clin Orthod. 1991;25(2):102-13

24. Itoh T, Chaconas SJ, Caputo AA, Matyas J. Photoelastic effects of maxillary protraction on the craniofacial complex. Am J Orthod. 1985;88(2):117-24.

25. Janson G, Toruno JÁ, Cruz KS, Henriques JC, Freitas MR. Tratamento e estabilidade da má oclusão de Classe III. R Dental Press Ortodon Ortop Facial. 2002;7(3):85-94.

26. Janson GRP, Canto GL, Martins DR, Pinzan A, Neto JV. Tratamento precoce da máoclusão de classe III com a máscara facial individualizada. R Dental Press Ortodon Ortop Facial. 1998;3(3):41-51

27. McDonald KE, Kapust AJ, Turley PK. Cephalometric changes after the correction of Class III malocclusion with maxillary expansion/facemask therapy. Am J Orthod Dentofacial Orthop. 1999;116(1):13-24.

28. McNamara JA. An orthopedic approach to the treatment of Class III malocclusion in growing children. J Clin Orthod. 1987;21(9):598-608

29. McNamara JA, Budron WL. Orthopedic facial mask therapy. In: Orthopedic and orthodontic treatment in the mixed dentition. Needham Press. 1995;15(5):283-95.

30. Marcotte EM. Extra oral. In: Marcotte EM. Biomecânica em Ortodontia. São Paulo (SP): Ed. Santos; 1993. Cap. 4, p. 83-97.

31. Martins DR. Tratamento da maloclusão de classe III com máscara de protração maxilar (Tração reversa). Ortodontia. 1994;1(1):1-31.

32. Moore GR. Heredity as a guide in dentofacial orthopedics. Am J Orthod Dentofacial Orthop. 1944:30(10):549-54

33. Merwin D, Ngan P, Hagg U, Yui C, Wei SHY. Timing for effective application of anteriorly directed orthopedic force to the maxilla. Am J Orthod Dentofacial Orthop. 1997;112(3):292-99.

34. Nanda R. Aspectos biomecânicos de uma máscara facial modificada para tração reversa. In: Nanda R. Estratégias biomecânicas e estéticas na clínica ortodôntica. São Paulo (SP): Ed. Santos; 2007. Cap. 13, p. 264-77.
35. Nartallo PE, Turley PK. Cephalometric effects of combined palatal expansion and facemask therapy on Class III malocclusion. Angle Orthod. 1998;68(3):217-24.

36. Ngan P, Wei SH, Hagg U, Yiu CK, Merwin, Stickel B. Effect of protraction headgear on Class III malocclusion. Quintessence Int. 1992;23(3):197-207.

37. Ngan PW. Tratamento das más oclusões de classe III nas dentaduras decídua e mista, In: Bishara, SE. Ortodontia. São Paulo (SP): Ed. Santos; 2004. Cap. 21, p. 375-414.

38. Ngan PW, Hagg U, Yiu C, Merwin D, Wei SH. Treatment response to maxillary expansion and protraction. Eur J Orthod. 1996;18(2):151-68.

39. Ngan PW, Hagg U, Yiu C, Wei SH. Treatment response and long-term dentofacial adaptations to maxillary expansion and protraction. Semin Orthod. 1997;4(3):255-64.

40. Oktay $\mathrm{H}$, Ulukaya E. Maxillary protraction appliance effect on the size of the upper airway passage. Angle Orthod. 2008;78(2):209-14.

41. Oltramari PVP, Garib DG, Conti ACCF, Henriques JFC, Freitas MR. Tratamento ortopédico da Classe III em padrões faciais distintos. R Dental Press Ortodon Ortop Facial. 2005;10(5):72-82

42. Pereira $C M$, Demito CF. Série aparelhos ortodônticos: máscara facial. Maringá (PR): Dental Press; 2008. p. 1-6.

43. Petit $\mathrm{H}$. Adaptations following accelerated facial mask therapy in clinical alteration of the growing face. In: McNamara J Jr, Ribbens KA, Howe RP, editors. Clinical Alterations of the growing face. Ann Arbor (MI): University of Michigan; 1983. Monograph 14, Craniofacial Growth Series, center for Human Growth and Development.

44. Proffit WR. Tratamento de problemas esqueléticos em crianças na fase de préadolescência. In: Proffit WR. Ortodontia contemporânea. Rio de Janeiro (RJ): Guanabara Koogan; 2002. p. 451-94.

45. Tanne K, Hiraga J, Kakiuchi K, Yamagata Y, Sakuda M. Biomechanical effect of anteriorly directed extraoral forces on the craniofacial complex: a study using the finite element method. Am J Orthod Dentofacial Orthop. 1989;95(3):200-7.

46. Thompson JR. The individuality of the patient in facial skeletal growth. Part 2. Am J Orthod Dentofacial Orthop. 1994;105(2):117-27.

47. Turley PK. Orthopedic correction of Class III malocclusion: retention and phase II therapy. J Clin Orthod. 1996;30(6):313-24.

48. Turley PK. Orthopedic correction of Class III malocclusion with palatal expansion and custom protraction headgear. J Clin Orthod. 1988;22(5):314-25.

49. Wagemans PA, Van de Velde JP, Kuijpers-Jagtman AM. Sutures and forces: a review. Am J Orthod Dentofacial Orthop. 1988;94(2):129-41

50. Yavuz I, Halicioglu K, Ceylan I. Face mask therapy effects in two skeletal maturation groups of female subjects with skeletal Class III malocclusions. Angle Orthod. 2009;79(5):842-8. 